\title{
The Crumbling Backbone of the Savannah Woman: Adjusting to the Declining Shea and Locust Tree Densities in Northern Ghana
}

\author{
Abdul-rahman Bunyamin $^{1^{*}} \quad$ David Anaafo $^{2}$ Jonas Ayaribila Akudugu ${ }^{3}$ Daniel Adusu ${ }^{2}$ \\ 1.Environmental Planning and Development Programme, University of Energy and Natural Resources, Sunyani- \\ Ghana \\ 2.Department of Environmental Management, University of Energy and Natural resources, Sunyani-Ghana \\ 3.Department of Planning and Sustainability, University of Energy and Natural resources, Sunyani-Ghana
}

\begin{abstract}
Rural women in Northern Ghana depend largely on indigenous forest resources, particularly Shea and locust bean trees as a major source of livelihood support. The fruits of these trees, are so essential to rural livelihoods that their collection and processing, are subjects of intense competition among rural women. Recent studies, however suggest a significant degradation of agroforestry parklands, and the population densities of Shea and locust bean trees. Using a case study approach, and employing participatory tools such as focus group discussions, interviews and structured observations, the study sought to unpack the experiences of rural women on the decline in these tree species, and examine how this new reality affects their major livelihood assets. The study found that, the decline in Shea and locust bean trees, affects the social, human and economic capital of rural women. Exploitation of other environmental resources, the use of improved Shea processing methods, and vegetable farming, were identified as major adaptation strategies among rural women. The study also found evidence of deep-seated historical and socio-economic factors militating against the successful adaptation of rural women. Consequently, the study highlighted the need for micro credit accessibility programmes, and gendered land tenure arrangements to support rural women in Agriculture.
\end{abstract}

Keywords: Agroforestry parklands, Shea trees, Locust trees, Livelihoods, Rural women, Response mechanisms. DOI: $10.7176 / \mathrm{JCSD} / 54-05$

Publication date: December $31^{\text {st }} 2019$

\section{Introduction}

The scientific consensus on the depletion of global environment in dramatic and unexpected ways is overwhelming (FAO, 2010). Particularly for sub-Saharan Africa, desertification and the threat of climate change are foremost (FAO, 2011). Ghana suffers this fate, as its forests cover, has substantially declined from about 7.5 million ha in 1990 to about 4.9 million ha in 2010, with approximately two percent rate of deforestation per year (FAO, 2011a). Empirical assessments, have often blamed the advent of climate change (Kirilenko \& Sedjo 2007), high population growth (Harte, 2007), and land use changes (Keenan et al. 2015; Shoyama et. al, 2018), as key drivers for the decline in these forest resources. Issues of property rights (Markussen, 2008), governance and management (Ashenafi, 2005; Dessalegn 2016), have also been illuminated in literature, as important factors that influence the sustainability of environmental resources.

The density of Shea and locust bean trees, which constitute a larger proportion of agroforestry parklands in Northern Ghana (Kent \& Bakaweri, 2010; Poudyal, 2011), has also not been spared by the ensuing environmental changes. Available scientific evidence, suggests a significant degradation of agroforestry parklands and the population densities of Shea and locust bean trees (Maranz, 2009; Poudyal, 2011). The depletion in Savannah environmental resources, dates back to at least early 1970s, as Haglund et. al (2011), observed that, the savannah woodland of northern Ghana, has degraded substantially from 1972 to 2000, declining about $22 \%$ between the periods. Beyond the general narrative on the decline in forest resources, specific studies on Shea and locust bean trees, depict them as being largely "all female affairs" across the entire value chain (Chalfin, 2004; Elias et. al 2006). These indigenous forest resources, play a critical role in the household economies of rural populations (Poudyal, 2011; Kent, 2018). Consequently, the fruits of these trees are so essential to rural livelihoods, especially women's, that their collection and processing are subjects of intense competition (Coulibaly-Lingani et. al, 2009). Shea butter and Dawadawa (condiment prepared from locust beans), constitute the main products of Shea and locust trees, and feature prominently in household meals of rural communities. Considered as gifts from God/gods, they play important roles in the survival strategies of dependent rural women (Schrekenberg, 2004).

The depletion of Shea and locust trees, is one critical factor which raises legitimate concerns on the sustainability of women's livelihoods. The future of these trees, the backbone of rural women's livelihood in the savannah agro-ecological zone, hangs very much on the balance. Studies on these sub-spontaneous trees reveal very interesting patterns. Most of these studies either emphasize the Shea tree as a non-timber forests product that supports rural livelihoods (e.g Pouliot, 2012), or concentrate on locust bean and its chemical composition (e.g Twumasi \& Awudza, 2013). These studies miss the opportunity of exploring Shea and locust trees as a 
bundle of community resources which complement each other in supporting the livelihoods of rural women especially in northern Ghana. Since Shea and locust bean are associate trees (Poudyal, 2011), and play very important roles in the livelihoods of rural women, concentrating on only one of them, partially addresses the problem, and also ignores the complementarities between them. Consequently, policies drawn from studies that partly address the problem, will most likely be unable to sustainably deal with the challenge. Attempts made by Poudyal (2011), to provide a comprehensive assessment of Shea and locust beans trees, provides a very good insight. He however limits the scope to various incentives that influence the management of these trees, thereby also missing the opportunity to critically examine the effects of decline in these trees on women's livelihoods. It is however important to note that, an understanding of the effects of decline in these species on rural women, provides the basis for policy formulation aimed at fashioning out customized women support programmes, for their sustainable living. This study therefore extends the boundaries of research on Shea and locust beans, by exploring the effects of decline in these sub-spontaneous trees on the livelihoods of rural women, and documents their response mechanisms.

The paper is organized into four sections. Following from section one which details the general motivations for the study, is the materials and methods section which describes the research location, and presents the techniques for data collection. While section three discusses field data, the last section recaps the key research findings, and outlines practical recommendations towards addressing the adaptation challenges of rural women.

\section{Materials and methods}

\subsection{Study area and justification}

The study was conducted in Sorugu, one of the 79 communities in the Sagnarigu district of Northern Ghana. Geographically, the district lies between latitudes $9^{\circ} 16^{\prime}$ ' and $9^{\circ} 34^{\prime}$ North and longitudes $0^{\circ} 36^{\prime}$ and $0^{\circ} 57^{\prime}$ 'West (GSS, 2014). Sorugu, the research area, is a rural community located about $10 \mathrm{~km}$ away from Tamale, the northern regional capital. It lies on the Tamale-Kumbungu road, about $1 \mathrm{~km}$ from the main road. Agroforestry parklands are the main features of the community's landscape, with Shea and locust bean trees found in cultivated parklands whose sustenance and densities have been greatly shaped by human and environmental factors. According to the community register, it has about 106 households and a population of a little over 800 inhabitants. It is homogenous in ethnic composition with all households belonging to the Dagomba ethnic group. With respect to traditional political structure, the community is ruled by a village chief in consultation with eight (8) sub-chiefs, who constitute the community's council of elders. The adult population in the community have livelihoods centered on agriculture, though many augment their agriculture production with petty trading and irregular wage labour. The agroforestry parklands of Sorugu community, is dominated by Shea and locust bean trees, which is traditionally and historically regarded as major livelihood support for local residents especially women. The proximity of the community to Tamale, the northern regional capital, exposes the community to rapid urbanization which comes in its wake, rapid depletion of both Shea and locust bean trees. This, coupled with agriculture intensification and mechanization and over exploitation of these tree resources leads to their substantial degradation. Furthermore, the community is a major player in the aggregation and processing of Shea butter and dawadawa, as it plays host to two Shea processing companies. The fact that, the principal livelihood activity and main income source of most women in the community is linked to these trees, and the rapid degradation of the community's vegetation, particularly locust and Shea trees, was what informed the choice of Sorugu as the study location. 


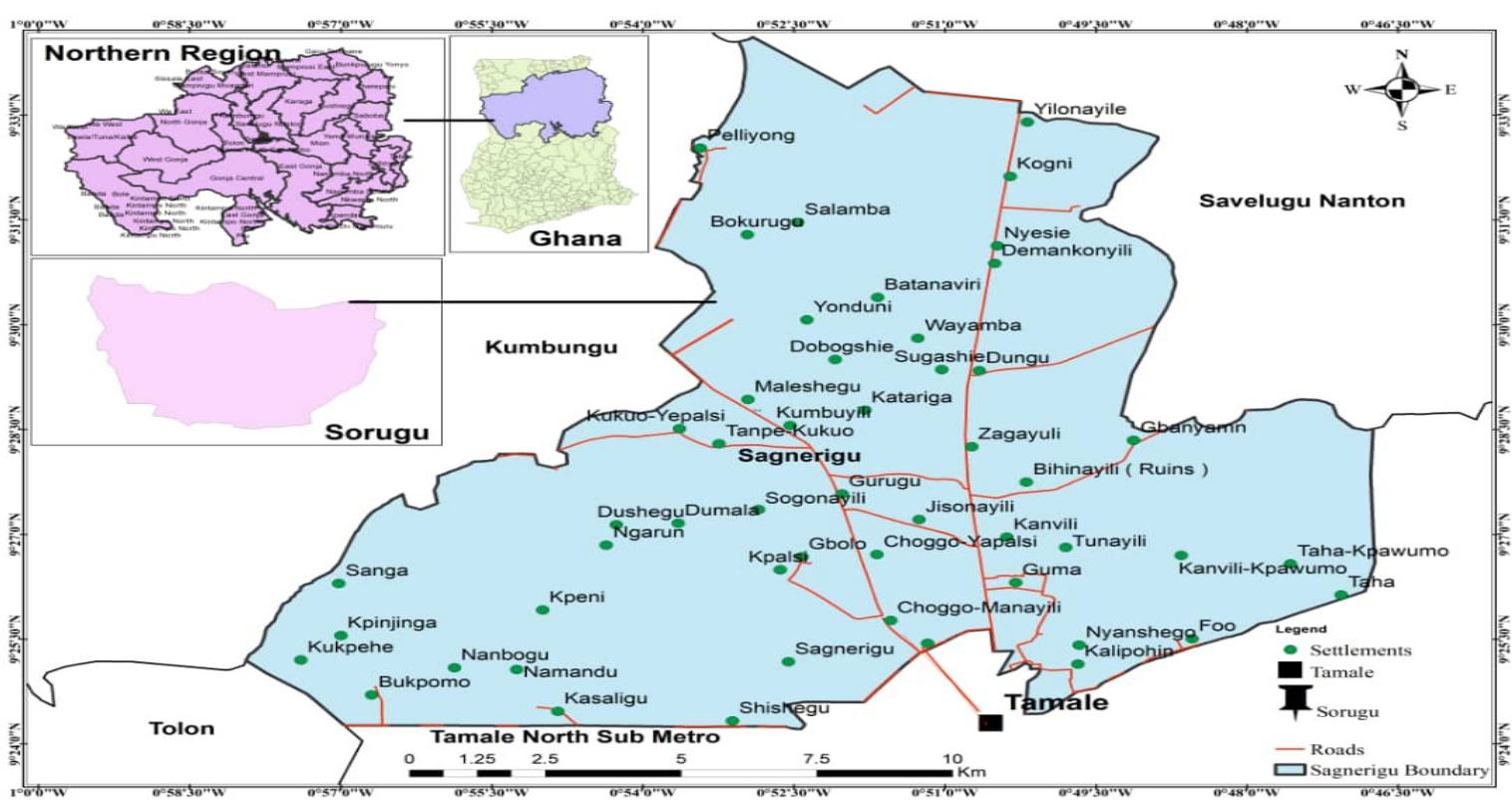

Fig. 1 Map showing the study area

Source: Author's construct (2019)

\subsection{Study design}

The study adopted a case study approach and employed qualitative data collection methods in achieving the research objectives. Exploring the effects of the degradation of these resources and response mechanisms of the most affected population, requires human centered approach with focus on depth rather than trends. That is, qualitative exploration provides more depth, by unpacking the effects of depletion of Shea and locust bean trees, and response strategies of local women. The study therefore aimed more at achieving ideographic objectives with less emphasis on generalizations.

\subsection{Sampling size and sampling approach}

Selection of key informants was based on the leadership positions of individuals in the community and engagement in the management and exploitation of Shea and locust beans. By virtue of their positions in the community as leaders of women Shea processing groups, they had in-depth understanding of the issues under discussion, and could appropriately respondent to pertinent research questions. Four women's group leaders were therefore interviewed as key informants. With respect to semi-structured interviews, purposive sampling was used in the selection of participants. The study therefore targeted women who were involved in Shea and locust bean activities. The sample size, was determined on the basis of empirical saturation. That is, interviews were conducted with as many eligible respondents as possible to the point when additional data no longer brought new insights to the major research themes under consideration. Consequently, saturation was attained at the $23^{\text {rd }}$ person, so a total of twenty-three (23) women were interviewed. This observation, is consistent with Creswell (1998), who reported that when heterogeneity and saturation becomes the focus of a study, interviewing 15 participants, \pm 10 is sufficient to attain quality data, capable of supporting a valid interpretation or inference.

It is important to note that, similar studies have relied on the concept of saturation, as a basis for sample size determination. For instance, Anaafo \& Guba (2017), in their study to assess the impact of land reforms on livelihoods of poor land users, employed the concept of saturation to support their choice of sample sizes for the various poor land users. Consequently, the study attained saturation at the $19^{\text {th }} 12^{\text {th }}$ and $15^{\text {th }}$ respondents, for female farmers, pastoralists and migrant farmers respectively. Similarly, Monique et.al (2017), in their assessment of saturation in qualitative research, also found that 16-24 interviews, were needed to attain a meaning saturation.

\subsection{Data collection methods and analysis}

The study employed some selected participatory techniques in collecting primary data on social and economic aspects of respondents, effects of decline on the livelihoods of women, as well as their response strategies. The use of these tools as opposed to other methods of data collection was deliberate for a number of reasons. The most important factor being the nature of the study which required a detailed and coherent account of personal experiences on the effects of forests resource depletion at the community level. As the name suggests, 
participatory tools allow for the involvement of the research subjects much more and throughout the process of the research, which was very key in meeting the primary objectives of the study. Primary data was analysed thematically based on the major issues under discussion.

2.4.1 Focus group discussions

Two focus group discussions, consisting of ten women each, were conducted in Dagbanli- the local dialect of the study community. The main purpose of the focus group was to discuss and obtain the various perspectives on the effects of forests resource depletion on the livelihoods of women, and their response strategies. The composition of each group was purposively managed. For instance, it was ensured that each focus group contained at least two women who were married to either a chief or sub-chief. These women were better placed to enrich the discussion, especially on issues of locust beans, since by traditional tree tenure arrangement, it is only the wives of designated chiefs who have primary access to the locust trees in Sorugu.

2.4.2 Semi-structured interviews

Semi-structured interviews were also used in the study. Major themes identified during the FGD's were used in designing a semi-structured interview guide which were administered to women. Consequently, issues that were not thoroughly discussed during FGD's, were further exhaustively explored during the interviews.

2.4.3 Key informants interviews

Leaders of the Shea and locust processing groups in the community were also interviewed as key informants to obtain in-depth understanding of the effects of these trees on Shea activities. This offered the opportunity to cross validate and triangulate information obtained from focus group discussions and semi-structured interviews. In total, four women leaders were interviewed.

\subsubsection{Structured Observations}

To further validate some of the issues raised during the FGD's and interviews, structured observations were also carried out as part of the data collection process. It is significant to note that interviews and focus groups discussions, even though play very important roles in data collection, are sometimes not sufficient to verify what people really do in relation to what people say they do (Russell, 2006). Consequently, directly observing research subjects and the physical environment of the study location, becomes very important, and complements other tools in attempt to give an accurate account of the people with respect to the phenomenon under study.

\section{Results and discussions}

3.1 Perception on decline of Shea and locust beans trees

The responses of women who are the direct beneficiaries of these resources, revealed the extent of decline in Shea and locust beans in the study community. Participants in the focus group discussion, observed that the number of trees has reduced significantly over the past few years, especially locust trees. Structured observations showed a number of Shea trees were cut for the purpose of fire wood and charcoal. There was some unanimity among focus group participants that, Shea and locust trees are on a serious decline, and therefore putting their livelihood on the brink. Factors such as use of chemical fertilizers and herbicides, mechanized agriculture and the conversion of farm lands into settlements, were identified as major factors threatening the sustainability of Shea and locust tree densities in agroforestry parklands (field data, January 2019). A respondent in recognition of the decline in Shea and locust trees, lamented that; "All the new houses you see on your way to the community, used to be our farmlands with a lot of Shea and locust trees scattered all around. The lands have been sold to strangers who decide what to do with them, including all tress found on them, which they cut at will" (A female Shea processor, Personal Interview, January, 2019).

Apart from the loss of trees to mechanized agriculture and settlement expansion, respondents also observed that, most of the matured parkland trees have exceeded their productive ages, and no longer of any economic value. An interesting observation, was also the near absence of young plants to take over from these old trees.

\subsection{Effects of Decline in Shea and Locust on Social Capital of women}

The interactions that occur between community members, and the networks and trust that individuals negotiate daily, are important assets that build opportunities, and reduce vulnerability to social and economic threats (Hanson, 2005). Such networks and personal interactions have proven more relevant in rural communities where populations are largely homogenous in ethnic compositions and significantly interdependent (Personal interviews, January 2019). A focus group discussion involving Shea pickers and processors in the study area, suggests that women in the community tend to organize themselves in groups based on common interest, for effective information sharing and resource mobilization. Particularly noteworthy, is the fact that, aggregators and other value chain actors facilitate the formation and formalization of these groups to expedite the conduct of their businesses. Development organizations, including state agencies, also leverage extensively on these groups to execute development programs and interventions in the study location. Consequently, women draw experiences from the groups they belong, and make critical livelihood decisions based on the information they obtain from such groups. Natcher (2015), explains social capital to mean a social web that integrates the benefits of family, 
friends, and their associated contacts that help to limit susceptibility to environmental stressors. Even though such groupings among women in the community are mainly for Shea and locust activities, they also tend to open other opportunities for social capital accumulation. For instance, they get to meet other Shea processors from neighboring communities and other people along the Shea and locust value chain. Consequently, the social capital of women, provides some level of insurance in times of adversities, and is considered a critical resource in determining the sustainability of livelihoods. The decline in Shea and locust beans, which has weakened the activities of these Shea processing groups in the community, fundamentally affects the social component of women's livelihood in three major ways.

First and foremost, the formation of these women groups for the purposes of Shea and locust activities, provide basis for social capital accumulation, and the platform for information sharing and support among rural women. Information sharing and all other benefits associated with belonging to these groups, has suffered a major setback, following the depletion of Shea and locust beans in the community. Observations at the community processing center, revealed it has not been in operation for the past two months. Respondents were of the view that, the ineffectiveness of the Shea processing groups, has by extension affected the flow of information with respect to new opportunities, market availability, access to resources, and as well deprived them the opportunity to discuss issues that bother on personal and collective interest.

Furthermore, access to credit facilities which was facilitated by the existence of these women groups on rotational or "Grameen" style basis, has also been affected significantly by the decline in Shea and locust beans. Individual women who intend to secure credit or loan facilities, now have to provide a tangible collateral as a proof of credit worthiness. This, according to respondents has affected their ability to fully diversify their livelihood activities.

The weakening of family ties, was another key dimension of the effects of depletion of Shea and locust beans on women's livelihood. The social and cultural contribution of Shea and locust beans in strengthening family ties was well recognized among rural women during focus group discussions and personal interviews. Products of these trees feature prominently in the domestic lives of women, and serve as an important gift when a woman gives birth to a new born and during festivals. Family members use dawadawa (main product of locus beans) every year to renew their family ties and to pledge their continuous support to other family members. In this regard, dawadawa which is the main product of the locust tree, is an appreciated gift in the study location and most rural communities in northern Ghana.

Personal interviews with women, showed that the decline in these resources have seriously constrained women in their attempts to support and sustain these social aspects of their lives. A woman who has her relatives in another community commented that; "I can no longer even get enough dawadawa for my daughter in-laws when they give birth, let alone to my family members in Malshegu (A nearby village). My family think I no longer appreciate them, and the occasional support I used to get from them has also stopped coming". (Personal interview, February 2019)

Asked whether it was compulsory to give them dawadawa at the end of harvesting season, she replied that; It is not compulsory to give them dawadawa, but it is done to show our appreciation to family members, and to remind them we are still part of them even though we are far away. This also makes them come to our aid when we are in distress. (Personal interview, February 2019)

The exchange of such gifts, even though not compulsory, serves as a unifying force that binds families together. The decline in Shea and locust trees and their products, is observed to impact negatively on this social aspect of many families, and considerably weakened many family ties among rural women (Personal interview, February 2019).

\subsection{Effects of decline in Shea and locust trees on energy needs of rural women}

Results from interviews and FDG's, revealed the role of these trees in meeting the domestic energy needs of rural populations. Respondents noted that Shea tree as fuel wood, comes in handy during child birth when the household energy expenditure increase significantly as preparation of food, boiling of herbs and water associated with the arrival of the new-born baby, adds to the existing energy expenditure of the household.

Apart from relying on trees directly as a source of energy, respondents also observed the combustible features of the residues from Shea butter production, which makes it a very good material in providing energy for cooking. The molten brownish substances left after Shea butter production, was dried into cakes which served as a good energy source. Field observations revealed a very light and dried substances which burns faster when used as a source of energy. A respondent noted that; "The waste generated from the butter production makes a very good fire material for cooking. We used to dispose it after extracting the Shea butter, but now we don't. We dig an open pit and pour the content inside which later dries and makes a good material for cooking". (Personal interview, February 2019)

These findings agree with that of Hatskevich, et' al (2011), who also in their study on Shea as a means for poverty reduction in northern Ghana, found that after Shea butter is extracted, the residue serves as excellent 
source of fuel for cooking. The residue which is known as kpambirigu among native speakers of Dangbanli, is gaining popularity as a very good energy source in most traditional communities in Dagbang. It is found to be more efficient and produce less smoke as compared with fire wood. Respondents, however, lamented their inability to generate enough quantities to meet their domestic energy needs.

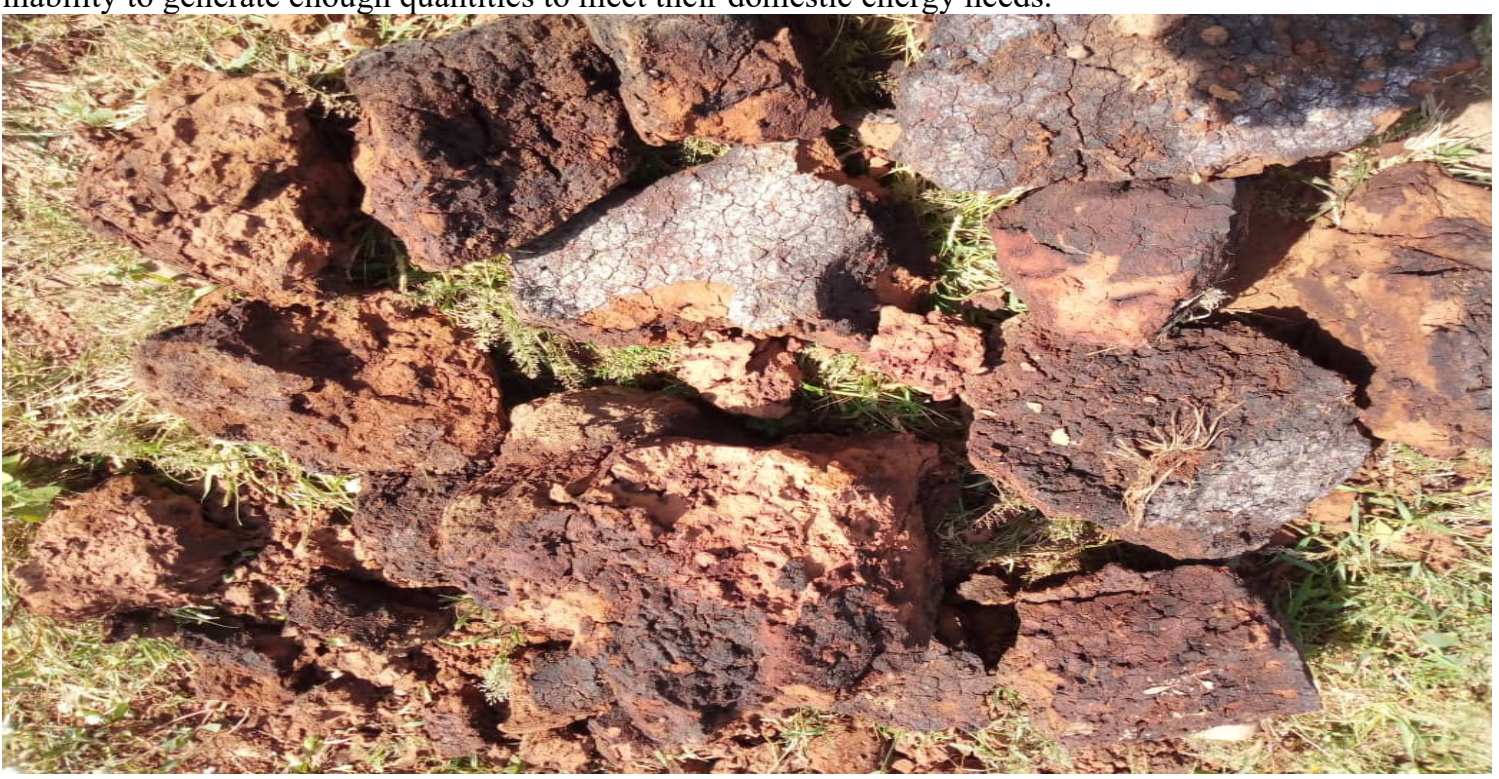

Fig. 2 End product of Shea process (Kpamburigu)

The residue of Shea butter production, which otherwise served as a good source of energy was in low supply due to reduction in butter production resulting from the decline of Shea nuts. However, the decline in Shea and locust bean trees in itself, was noted not to have a significant effect on the energy needs of rural women, as the Shea and locust trees were only part of the numerous energy options available to rural women (Personal Interviews, January, 2019)

It is, however, important to document that, the decline in financial resources of women, as a result of the depletion in Shea and locust bean trees, was identified to have a spillover effect on the energy options of rural women. Even though women demonstrated some level of awareness on other sustainable energy sources like LPG and electric stoves, the lack of financial capability to take advantage of such energy sources, has remained the major effect of decline in Shea and locust bean trees on the energy needs of rural women.

\subsection{Effects of decline in Shea and locust bean on human capital}

Shea and locust bean trees are natural capital known for their multi-purpose roles in northern Ghana, and therefore contribute significantly to the human capital of rural populations. Human capital, according to the DFID components of livelihoods, encompasses the health, nutrition and the skills aspects of livelihoods. With respect to nutrition, Shea butter and dawadawa constitute the main products of Shea and locust trees respectively, and feature prominently in the household meals of many rural communities. Responses from multiple interviews, project Dawadawa, as an inseparable part of local dishes, and used traditionally in naming ceremonies, funerals and other social events mainly because of its perceived nutritional value and health attributes. Sharing her experience on the importance of Shea and locust beans, a respondent asserted that; Shea and locust bean products play very important roles in our lives. They feature in almost all traditional meals in this community. Dawadawa adds flavour to food, and has a very high nutritional value when used for cooking. So we mostly don't cook without it (Personal interview, February 2019).

This corroborates the positions of Elemo, et. al (2011), who found locust beans to be an important source of nutrients including potassium, phosphorus and amino acids. The fermented locust seed, according to Codjia et al (2003), contains about 30 percent to 40 percent protein, an average of 15 to 20 percent carbohydrates, including fats and minerals.

Particularly for Shea butter, which is the main product of Shea trees, respondents were of the view that, it helps medically in the treatment of minor fractures and skin related diseases. The findings from interviews and FGD's on the health benefits of these products, agrees with Hatskevich et al., (2011), who posits that Shea and its products, especially butter, is almost magical in its healing ability on burns, skin diseases and stretch marks, and therefore plays a very critical role in the health needs of rural populations. Similarly, the findings also resonates with the work of Dogbevi (2009), who shared an earlier view that Shea products possess characteristics that makes it suitable as a base for certain traditional ointments for the healing of sprains and broken bones.

Within the study area, and most parts of Dagbang traditional area, locust beans are fermented and used in 
preparing a local potion called Zilinbong (a liquid prepared from locust beans, usually with a very strong scent). This, is used in the treatment of stroke and other stomach ailments. It is also administered to younger children to help fight against diseases associated with infancy. It was unanimously agreed during the women's focus group discussion that, the Shea butter and Zilinbong are the two most important products kept by women for the treatment of minor ailments in their households. Respondents shared the opinion that, Shea butter plays a critical role in facilitating the healing of male children who go through the process of traditional circumcision. After performing a circumcision procedure on a male new born at the community level, the Shea butter is prescribed to aid the healing of sores left behind by the procedure. The medicinal value of these products was further stressed by a respondent during an interview who pointed out that; "Shea and locust products are very important to our health. The Zilinbong is what we use as first aid when someone develops a stomach ailment, and we use the Shea butter when a child or adult sustains a minor domestic injury. They support the health needs of every household" (Personal interview, February 2019)

The decline in Shea and locust beans has, however affected the human capital of women, especially nutrition and health. Experiences shared by rural women, show an emerging nutrition transition, where Shea and locust products are giving way for industrially manufactured or processed substitutes which arguably do not provide the same organic composition as locally processed Shea butter and dawadawa. Respondents observed that the consumption of these substitutes come with some perceived health implications, which were originally not experienced by community members, including women. These experiences by local women is in line with the position of Popkin (2001), who found that, nutrition transition from forests products leads to increasing rate of nutrition-related diseases including cardio-vascular diseases. Ibarra et al. (2011), also notes that the health implications of decline in forests resources, is associated with increased dependence on outside food sources and loss of health benefits of traditional and organic wild forests foods.

Furthermore, the inability of rural women to meet the high cost of medical services, is also fundamentally linked to the effects of decline in Shea and locust bean trees. According to respondents, sicknesses that require the attention of professional medical practitioners, are usually managed at the village setting, largely because of their inability to meet the financial obligations associated with contemporary medicine. The decline in Shea and locust beans trees, which is recognized as the main source of income for women, has consequently affected their ability to explore the appropriate medical services, even when it becomes critical for them to do so. In conclusion, the decline in Shea and locust trees has affected the health, nutrition of rural women, which constitute an integral part of human capital.

\subsection{Effects of decline in Shea and locust beans on economic capital of women}

The economic/financial contribution of Shea and locust beans trees, is well documented in literature (e.g Shreckenberg, 1996, Poudyal; 2011 Kent, 2018; York \& Garden, 2018), and has remained an important component of women's livelihoods. Results from responses, show that Shea and locust beans contribute economically to the livelihoods of women in two major ways. First, respondents identified picking and marketing of Shea and locust, as their main source of financial support. Shea and locust collected from individual farms are either sold raw to prospective buyers or processed into Shea butter and dawadawa for onward sales which serve as a source of income for rural women. Secondly, providing labour at a private Shea processing center located in the community was also identified as another way by which Shea contributes to their financial needs. There was, however, some level of difficulty in assessing the precise monetary or financial contribution of Shea and locust products to rural households. The study found a significant proportion of these products being mostly consumed at the household levels, making it difficult to quantify in monetary terms its real economic returns, especially the locust products.

Consequently, figures concerning the economic value or returns of these resources were seriously underestimated among rural populations (Interviews, January 2019). Admittedly, an attempt to give specific figures in terms of economic or financial values without considering what is consumed at household levels, may be grossly misleading. This is particularly true, as the products consumed at household levels would otherwise come with some price tags, if they were bought from the open market.

This problem of underestimation, was more nuanced in the case of dawadawa, where almost every household preserve the product strictly for household consumption, social events and as gifts to strengthen family and social ties. For instance, the study reveals that almost 95 percent of harvested locust products are retained for domestic use. This suggests a potentially significant margin of error when estimated in monetary terms without considering what is consumed at household levels. The results, however, indicate a much lower quantity of about 20 percent of Shea nuts being retained for domestic use, while the remaining is sold to meet other livelihood needs. This partly explains why the financial contribution of Shea products to rural households is more profound than that of locust beans.

These findings on the low economic contribution of locust beans, is antithetical to the findings of Farayola, Okpodu \& Oni (2012), who concluded that, economically, locust bean processing is found to provide a 50 
percent rate of return on investment among actors on the value chain including pickers. It should be noted that, even though the nutritional value of legumes, including locust beans, is gaining attention globally, as found by Ajayi, et.al (2018), this might not necessarily translate into increase in income of locust pickers, as locust beans are in low supply or almost extinct and cannot meet the increasing market demand.

The decline of Shea and locust beans has greatly affected the economic and financial resources of women. The act of saving in anticipation of unforeseen environmental stressors, is very critical to sustainable livelihoods. The decline in these resources has affected the ability of women to save, create reserves and buffers needed to take care of uncertainties that may come with unfavorable environmental conditions. The economic effects of the decline, is also intrinsically linked to human capital which entails the health, nutrition and skill development needs of rural women. Field results reveal that reduction in the financial resources of women, emanating from the decline in Shea and locust as a natural capital, has affected the basic food needs of rural women. Proceeds from Shea and locust bean are no longer adequate to supplement the household with food stuffs that are not readily available on family farms. Women rely on income from these products to purchase other food ingredients aimed at balancing the household diet. Women are, however, constrained financially, and quite incapable of performing the same role. Consequently, this affects the quality of food and comes with its own health implications including malnutrition.

The financial effects of the decline in Shea and locust trees, was also observed to have some spillover effect on the skill development of rural women and their households. Respondents were asked to give opinion on how the decline in these resources has affected them in terms of their ability to embark on skill training and also support their children's education. The decline in these resources tend to affect the ability of women to engage in skill development which normally require some initial capital. Respondents who developed interest in tailoring, bead making and other skills that were not traditional to the community, were constrained financially and not able to meet the demands of such skill developments.

\subsection{Response mechanisms}

Interviews and women's focus group discussions showed a considerable number of autonomous response strategies by women, with few external training support programs from Non-governmental organizations (NGO's) to aid the adaptation of women. These response mechanisms fall within the categorization of Portia, Reuben, Isaac, \& Godfred (2018), who reported that adaptation measures are either initiated internally by individuals within communities, or from organizations outside the community in response to decline in their traditional livelihood sources. The major adaptation strategies are further discussed below.

3.6.1 Intensification of vegetable farming through inter-cropping

Traditionally, women do not own land in Sorugu, and by extension, are not supposed to own individual farms, but rather contribute to the labour requirements of the household farm, which normally belongs to the husband. Culturally, women only take advantage of the labour they provide on the husband's farm, to also grow vegetables within the same farm in the midst of major family crops. Proceeds of such vegetables from intercropping, go to individual women and partly supplements the household's income.

The decline in Shea and locust beans, has resulted in women's renewed interest, and intensification of vegetable inter-cropping on husbands' farms, as a response to the decline in Shea and locust beans. Even though growing vegetables along the major family crops, has been a regular activity of women over the years, it was usually meant to supplement household food requirements, without any commercial intention. The decline in Shea and locust bean in the community has brought a new dimension to this activity as an adaptation strategy. There is an increased engagement of women in intercropping within their husband's farm far more than they used to, and respondents have attributed that to the decline in Shea and locust bean trees. Inter-cropping, according to respondents, generates income that supports their basic livelihood needs. This income is only obtained during the regular farming season since they rely on only rainfall as source of water for such activities. A woman in a focus group discussion aptly put it that: "the money I make from inter-cropping on my husband's farm is used in purchasing food stuffs for the household. This reduces the burden on the income generated from my own regular farming activities" (Focus Group Discussion, January 2019)

3.6.2 Modernized and improved Shea processing methods

As part of the response to the decline in Shea and locust bean products, women have adopted a new and improved processing method to increase their output. Rural women undergo training from NGO's, on the use of new processing methods which involves parboiling of Shea nuts at prescribed temperatures and moisture levels to reduce waste, whiles increasing output. Responses from FGD's, suggest there has been an increase in Shea butter produced per kilogram of Shea nut following the introduction of the new method. Some respondents were, however, still skeptical about the prospects of the new processing method. Some respondents opined that, this method requires higher expertise, and rather reduces their output if utmost care is not taken in the production process. 
3.6.3 Exploitation of other available environmental resources

Through personal observations and interviews, it was found that, the Neem (Azadracata indica) was gradually replacing the locust bean and Shea tree. It fills the void created by the diminishing Shea and locust bean trees through the provision of income. Women harvest Neem fruits and extract oil from the seeds, which is used for the treatment of sores and stomach ailments, and also sold at the Tamale and other nearby markets for income. The branches are used for staking yam and tomatoes farms and in roofing houses. The use of Neem branches for roofing, and the seeds as a source medicine, has gained so much currency that it has assumed some commercial value in the community.

3.6.4 Rice and groundnut processing

Apart from farming related activities in response to the degradation of these forests resources, women also engage in rice and groundnut processing to boost their income levels. Rice and groundnut, are abundant in northern Ghana, and offer a good opportunity for women's livelihood. Among rural women, adding value to rice and groundnut has been an avenue for diversification of income sources. Most respondents were engaged in processing of rice and groundnut as a way of generating income for their personal and household needs. It has proven to be a viable venture for rural women as it is a year-round activity and enjoys a regular market demand (Personal interviews; January-February, 2019). According to a respondent, rice and groundnut processing, even though does not generate much income as compared to farming, does not also require huge initial capital outlay. 3.6.5 Irregular wage labour

Women who have been involved in Shea processing for years, rely on their experiences to engage in paid labour as a source of income towards mitigating the effects of the decline in Shea and locust trees in the community. Experienced women who no longer obtain economic quantities of Shea from their own farms, offer their service to the Shea processing company in the community for daily wages or on profit sharing basis. According to respondents, the company usually engage them to process Shea into butter for the mutual benefits of the two parties. This usually entails either sharing the accrued profit in agreed percentages or giving the women a quantity of the butter produced.

\subsection{Factors affecting the adaptation of women}

Despite the progress made so far by women in response to the decline in Shea and locust beans, respondents reported some major factors that militate against their successful adaptation. Among these factors include the following.

3.7.1 Prevailing socio-cultural arrangements

Responding to interview questions, women were of the view that, the existing socio-cultural arrangements have remained an important factor affecting their ability to respond or adapt to the challenging situations associated with forests resource decline. Existing socio-cultural arrangements, showed men still exercise some greater level of control over women, to the extent that land ownership in the community was still entirely under the control of men. Women do not own land in the community, just like other parts of the Dagbang traditional area. On this basis, any woman who intends to put land into economic activity, will have to do so with the permission of the appropriate person who are mostly men. Women who desired to explore agriculture as a response mechanism, still passed through their husbands in order to acquire the appropriate land. The husbands therefore have the opportunity to regulate the farm sizes of woman, to allow her enough time to still contribute to the labour requirement of the husband. A respondent on her level of engagement in agriculture remarked that; "Next year, I am going to expand my farm if I get the permission and support of my husband. I wanted to expand it last year but I didn't get approval from him. I hope to do so this coming season”. (Personal interview, January 2019)

This statement by the respondent, revealed that, even though farming is becoming popular among women, and fast replacing Shea and locust activities, the prevailing cultural arrangements, which endorsed male dominance at all levels of engagement in the community, put women at a serious disadvantage. Women are confined to small land sizes and rely heavily on family labour, which undeniably are features of subsistence farming, and not the commercial agriculture as desired by rural women.

3.7.2 Nature and structure of rural households

The structure of households, also featured prominently during the interviews, as another factor affecting women's adaptation. Responses showed the structure of polygamous households tends to affect the ability of women to respond to the decline in forest resources. Out of the 23 women interviewed, 19 were from polygamous homes, projecting polygamy as a dominant social-cultural practice in the study area. Larger and polygamous homes tend to encourage land fragmentation among co-wives, thereby affecting the area of land available to women who intend to expand their farms. A respondent in an interview, lamented that she has been trying to engage in commercial vegetable farming, but her husband has three other wives, with who she shares a five-acre land. This according to the respondent has affected her intention to expand her farm. Another respondent in an interview, revealed that her farm was doing well previously when she was the only wife of the husband, but the size was reduced when the husband re-demarcated the land to make provision for his newly 
wedded wife. Even though larger or polygamous households are argued to contribute significantly to farm labour, women respondents shared the opinion that, it rather influenced land fragmentation and determines what is available to each woman in terms of land allocation.

3.7.3 Lack of credit facilities

The prevailing lack of credit facilities, was also identified by respondents as another factor. It is acknowledged that all economic activities require some level of capital injection to accomplish. Respondents who are engaged in agriculture, complained about the cost of farming and the unavailability of credit facilities to support their farming activities. The cost of labour and farm inputs are reported to be very high, beyond what an average woman in the community can afford. Respondents are therefore limited to family labour and rudimentary farming tools, as opposed to their male counterparts whose farms are highly mechanized. This has further constrained women in their attempt to expand their farms, and has deterred those yet to make an attempt.

Respondents were, however, divided on which of these problems presents the highest challenge to their attempt to diversify their livelihood sources. Seven out of the 23 interviewees maintained that, current cultural arrangements which limits their access to land, is the most important factor hindering their attempts to engage in agriculture. Ten also considered the lack of credit facilities as the biggest threat to their ability to adapt to the decline in Shea and locust trees. The remaining six respondents, also observed the nature and composition of households as the most outstanding factor hindering their ability to diversify their income portfolios.

On ways to enhance their adaptation to the decline in Shea and locust bean trees, all respondents proposed a more flexible land tenure arrangement that accommodate the interest of women. This, according to respondents will ease their access to land to boost their farming activities. Respondents also stressed the importance of credit facilities in enhancing their livelihoods. According to them, access to credit facilities would help meet the high cost associated with agriculture beyond subsistence.

\section{Conclusion and Recommendations}

The study employed focus group discussions, semi-structured interviews, structured observations and key informant interviews, to unravel the effects of decline in Shea and locust trees on the livelihoods of dependent rural women. It explored the strategies adopted by rural women in response to the decline, and also documented key factors militating against women's efforts in diversifying their income portfolios.

Rural women adopt both autonomous and planned measures in response to the decline in these forest resources, as they engage in diverse activities to mitigate the impact of threats that come with the decline in these resources. Unfavourable socio-cultural practices, land tenure arrangements, lack of credit facilities and the nature and composition of rural households, have remained the major impediments to the diversification efforts of rural women.

Study recommends that, the full economic potential of Neem tree and its products, which are fast gaining economic value within and outside the study community, should be explored further by government and other development agencies. Planned actions should target the growing of Neem, as well as building the capacity of women in Neem seed oil extraction, to help sustain their livelihoods.

Secondly, the study recommends that, the Microfinance and Small Loans Center (MASLOC), as part of their broader policy on micro credit accessibility, should develop a model that targets rural women in the savannah zone. This model will provide the needed income to women who seek to engage in farm expansion, petty trading or rice processing as a response strategy towards the decline of Shea and locust bean trees. The youth in agriculture program should also be expanded to cover rural women, to train them on new and improved methods of agriculture to help them diversify their income portfolios.

Lastly, the study recommends that, the National Council for Civic Education (NCCE), and the Ministry for Women, Children and Gender, should collaborate in rolling out sensitization programs on the importance of gender sensitive land tenure arrangements in the Savanna zone. This will allow for changes that accommodate the interest of women in their attempt to secure agriculture lands to improve their livelihoods.

\section{Acknowledgement}

The Authors wish to express their profound gratitude to the Chief of Kpalsogu, for the acceptance and assistance accorded the research team during our regular visits to the community. And also to Adam Yidana Abass for his immense field support.

\section{References}

Ajayi, K., Adepoju, O. T., Taiwo, O. M., Omojola, S. T., \& Aladetuyi, M. E. (2018). Nutritional potential of underutilized gum arabic tree seeds (Acacia nilotica) and locust bean seeds ( Parkia biglobosa). African Journal of Food Science, 12(8), 196-203.

Alhassan, S. (2018). The Shea tree, our heritage: Sustaining Ghana's Shea Industry. In Inaugural Lecture, July 20 (pp. 1-5). Tamale: Uds. 
Ashenafi, Z. T. (2005). Indigenous Common Property Resource Management in the Central Highlands of Ethiopia. Human Ecology, 33(4), 539-563.

Anaafo, D., \& Guba, B. (2017). Do land reforms have adverse impacts on the livelihoods of poor land users? Evidence from the Nkoranza South Municipality, Ghana. Canadian Journal of African Studies, 51(2), 293318.

Chalfin, B. (2004). Shea butter republic: State power, global markets, and the making of an indigenous commodity. London: Routledge.

Codjia T, Assogbadjo E, E. R. (2003). Diversity and valorization of Benin's food forest plant resources. Cashiers Agriculture, 12(5), 321-331.

Coulibaly-Lingani, P., Tigabu, M., Savadogo, P., Oden, P. C., \& Ouadba, J. M. (2009). Determinants of access to forest products in southern Burkina Faso. Forest Policy and Economics, 11(7), 516-524.

Creswell, J. W. (1998). Qualitative Inquiry and Research Design: Choosing among Five Traditions. Thousand Oaks, CA: Sage.

Dessalegn, M. (2016). Threatened common property resource system and factors for resilience : lessons drawn from serege -commons in Muhur, Ethiopia. Ecology and Society, 21(4).

Dogbevi, E., K. (2009). Shea nut has economic and environmental values for Ghana. Accra: Sekaf Ghana Ltd. Publication.

Elemo, G. N., Elemo, B. O., Oladunmoye, O. O., \& Erukainure, O. L. (2011). Comprehensive investigation into the nutritional composition of dehulled and defatted African locust bean seed ( Parkia biglobosa ). African Journal of Plant Science, 5(5), 291-295.

Elias, M., Bayala, J., \& Mohamadi, D. (2006). Impediments and innovations in knowledge sharing: the case of the African shea sector. KM4D, 2(1), 52-67.

Ellis, F. (2011). Rural Livelihood Diversity in Developing Countries : Evidence and Policy Implications. ODI Natural Resource Perspectives 40, 223-228.

FAO. (2010). Global Forest Resources Assessment 2010. FAO Forestry Paper, 163, 350

FAO. (2011).The forest sector in the green economy. Nature and Fauna, 26(1), 1-4.

Hanson, K. T. (2005). Landscapes of survival and escape : social networking and urban livelihoods in Ghana. Environment and Planning, 37, 1291-1310.

Haglund, E., Ndjeunga, J., Snook, L., \& Pasternak, D. (2011). Dry land tree management for improved household livelihoods: Farmer managed natural regeneration in Niger. Journal of Environmental Management, 92(7), 1696-1705.

Harte, J. (2007). Human population as a dynamic factor in environmental degradation. Popul Environ, 28(5), $223-236$

Hatskevich, A., Jeníček, V., \& Darkwah, S. A. (2011). Shea industry - a means of poverty reduction in northern in Ghana. Agricultura Tropica et Subtropica, 44(4), 223-228.

Israr, M., Yaseen, A., \& Ahmad, S. (2017). Sustainable Rural Development and Livelihood Sources of the Rural Households in Mountainous Pakistan. American Journal of Rural Development, 5(4), 97-105.

Keenan, R. J., Reams, G. A., Achard, F., de Freitas, J. V., Grainger, A., \& Lindquist, E. (2015). Dynamics of global forest area: Results from the FAO Global Forest Resources Assessment 2015. Forest Ecology and Management, 352, 9-20.

Kent, R. (2018). "Helping" or "Appropriating"? Gender Relations in Shea Nut Production in Northern Ghana. Society \& Natural Resources, 31(3), 367-381.

Kirilenko, A. P., \& Sedjo, R. A. (2007). Climate change impacts on forestry. PNAS, 104(50), 19697-19702

Malterud, K. (2001). Qualitative Research: Standards, Challenges and Guidelines. The Lancet, 358(9280), 483488.

Markussen, T. (2008). Property Rights , Productivity, and Common Property Resources : Insights from Rural Cambodia, 36(11), 2277-2296.

Maranz, S. (2009). Tree mortality in the African Sahel indicates an anthropogenic ecosystem displaced by climate change. Journal of Biogeography, 36(6), 1181-1193.

Monique, M.,H., Bonnie, N., K., Vincent, C.,H., (2017). Qualitative health research 27(4) 591-608.

Natcher, D. C. (2015). Social capital and the vulnerability of aboriginal food systems in Canada. Human Organizations, 74(3), 230-242.

Popkin, B., M. (2001). The nutrition transition and Obesity in the Developing world. The Journal of Nutrition, $131(3), 8715-8735$

Poudyal, M. (2011). Chiefs and Trees: Tenures and Incentives in the Management and Use of Two Multipurpose Tree Species in Agroforestry Parklands in Northern Ghana. Society and Natural Resources, 24(10), 37-41.

Pouliot, M., Treue, T., Obiri, B. D., \& Ouedraogo, B. (2012). Deforestation and the limited contribution of forests to rural livelihoods in West Africa: Evidence from Burkina Faso and Ghana. Ambio, 41(7), 738-750. 
Samuel, J., Shah, N. and H. (2005). Mobile Communications in South Africa, Tanzania and Egypt: Results from Community and Business Surveys. The Vodafone Policy Paper Series, 2, 44-52.

Schrekenberg, K. (2004). The Contribution of Butter to Local Livelihoods in Benin. In Case Studies of Nontimber Forest Product Systems (2nd ed., pp. 91-113).

Twumasi, S. K., \& Awudza, J. A. M. (2013). Chemical analyses of aqueous extract of Parkia biglobosa fruit husk collected from Northern Ghana. Scientific Research and Essays, 8(14), 589-595. 